\title{
Deuteronomy 28 and Tell Tayinat
}

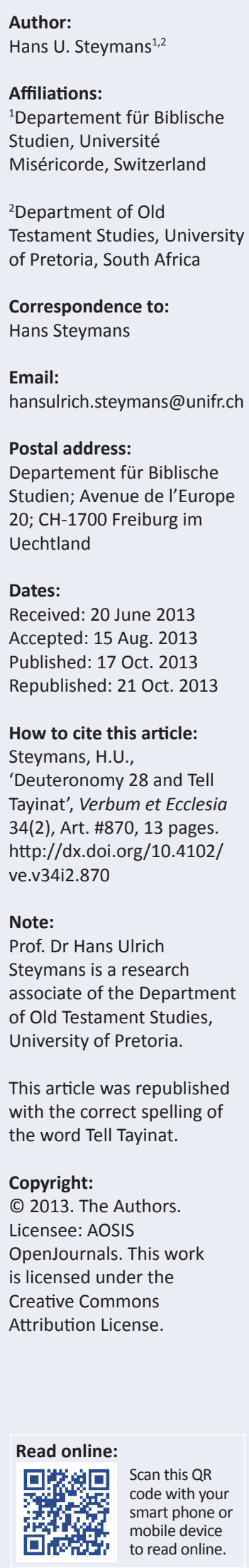

The discovery of Esarhaddon's Succession Treaty (EST) at Tell Tayinat confirms the Assyrian application of this text on western vassals and suggests that the oath tablet was given to Manasseh of Judah in 672 BC, the year in which the king of Assyria had all his empire and vassals swear an oath or treaty promising to adhere to the regulations set for his succession, and that this cuneiform tablet was set up for formal display somewhere inside the temple of Jerusalem. The finding of the Tell Tayinat tablet and its elaborate curses of §§ 53-55 that invoke deities from Palestine, back up the claim of the 1995 doctoral thesis of the author of this article that the impressive similarities between Deuteronomy 28:20-44 and curses from $\S 56$ of the EST are due to direct borrowing from the EST. This implies that these Hebrew verses came to existence between $672 \mathrm{BC}$ and $622 \mathrm{BC}$, the year in which a Torah scroll was found in the temple of Jerusalem, causing Josiah to swear a loyalty oath in the presence of Yhwh. This article aimed to highlight the similarities between EST § 56 and Deuteronomy 28 as regards syntax and vocabulary, interpret the previously unknown curses that astoundingly invoke deities from Palestine, and conclude with a hypothesis of the composition of the book of Deuteronomy.

\section{Introduction}

Historical critical assessment makes prophets disappear. At the meeting of South African exegetes in 1993, Jurie le Roux reported on the discussion of Robert P. Carroll's commentary on Jeremiah. In Carroll's view, the historical Jeremiah is buried under many layers of interpretation and cannot be recovered anymore (Carroll 1986; Le Roux 1994:63). Le Roux (1994) asks:

Is it possible that Carroll's ideology prevented him from understanding the events of the sixth century $\mathrm{BC}$ ? Is there really no link between a prophet and the book bearing his name? (p. 89)

In Karl-Friedrich Pohlmann's eyes, Ezekiel has vanished behind the several golah-oriented editorial layers, a prophetical book and a collection of dirges (Pohlmann 1996:27-41, 2008:96). For Pohlmann's doctoral student, Susanne Rudnig-Zelt, almost the complete book of Hosea stems from Persian times - the oldest layer being some sayings about the foulness of Epharim (Rudnig-Zelt 2006:257). Rainer Gregor Kratz leaves barely 14 verses spread over chapter 3 to 6 of Amos. The rest is editorial work, whose dating may be assigned to a period after 722 BC or even later ages (Kratz 2011:328, 324 n. 40). The prophets' disappearance is severe, because Deuteronomy 28 has been dated on an inner-biblical basis through links with Jeremiah, Hosea and Amos. What foothold for dating in the Pentateuch can prophetical works still give when exegetes like Caroll, Pohlmann and Rudnig-Zelt remove the origin of a prophetical book far from the lifetime of the eponymous prophet and push the dating of its composition downward through history to late Persian times? Some foothold for dating Deuteronomy 28 may be given by extra-biblical evidence.

Archaeologists make texts appear. In 2009, the Tayinat Archaeological Project discovered a new exemplar of Esarhaddon's Succession Treaty (EST ms T-1808) in the inner sanctum of Building XVI - a Neo-Assyrian temple at Tell Tayinat, ancient Unqi, capital of the Neo-Assyrian province of Kullania. Figure 1 depicts the very act of excavating this cuneiform tablet. This document was previously known from a group of at least eight tablets from Nimrud, ancient Calhu, which were sealed with three divine seals of the god Assur and found in the throne room of the temple of Nabû (Ezida). The treaty tablet from Tell Tayinat was displayed in antiquity in the temple's inner sanctum. It measures $40 \mathrm{~cm} \times 26 \mathrm{~cm}$ and, like the Nimrud manuscripts, it must be rotated along its vertical axis in order to read the reverse. It is pierced through its horizontal axis so that it could be fixed by a stick that was pushed into the tablet's hole and hooked into a stand. The treaty partners are the anonymous governor (bēl pāhiti), 16 anonymous individuals designated by occupation and, finally, all inhabitants of the province subject to the governor (Lauinger 2012:87, 90). This find corroborates hypotheses about the influence of the EST on Deuteronomy 28. It dismisses Liverani's claim that the EST was only meant for Median bodyguards of the Assyrian court. It 


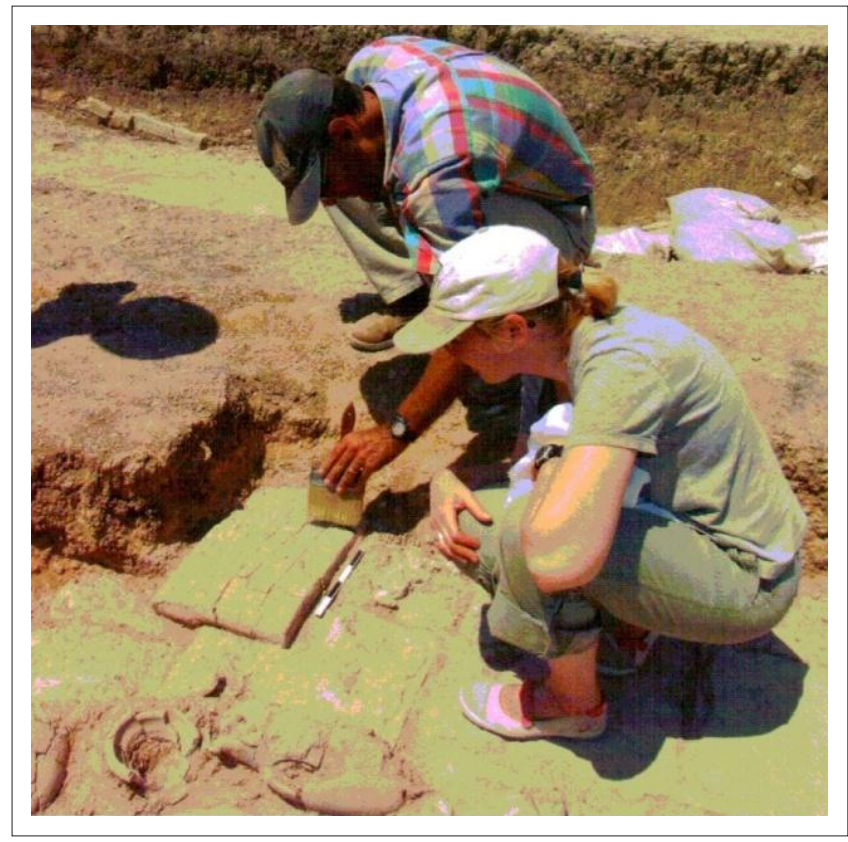

Source: Photo by Jenifer Jackson, courtesy Tell Tayinat Archaeological Project, University of Toronto (Harrison, T.P., 2009, 'Neo-Hittites in the "Land of Palistin". Renewed investigation at Tell Ta'yinat on the Plain of Antioch', Near Eastern Archaeology 72[4], 186)

FIGURE 1: Excavation of the tablet of Esarhaddon's Succession Treaty in temple $\mathrm{XVI}$ at Tell Tayinat.

also dismisses the idea of an Aramaic translation of the EST used for Western vassals of Assyria. That the Assyrian royal chancellery produced an official Aramaic translation of the EST is unlikely due to the sophisticated rhetoric effectiveness of the language used in the Assyrian text. Word repetitions in multitudes of seven and eight render the EST a message appealing to god and man - a piece of art that only gods and well trained scribes could really appreciate (Steymans 2003).

It has been my privilege several times to attend the Propent seminars, organised by Jurie le Roux, at Hammanskraal near Pretoria. It is with pleasant memories of stimulating discussions with South African, Dutch, Belgian and German colleagues gathered there that I contribute this evaluation of the impact of the EST manuscript from Tell Tayinat on hypotheses about the origins of Deuteronomy to his Festschrift.

Direct borrowing from the EST in order to create Deuteronomy 28:20-44, the oldest layer of the chapter, implies that these Hebrew verses came into existence between 672 BC, the year when Esarhaddon had all his empire and vassals swear a loyalty oath or treaty (the Assyrian term of this sort of text being adê) to adhere to the regulation for his succession and $622 \mathrm{BC}$, the year when a Torah scroll was found in the temple of Jerusalem causing Josiah to swear a loyalty oath in the presence of Yhwh. Such an anchor for the dating of a Biblical text does not correspond with those scholars who want Deuteronomy to stem from the lifetime of Moses, that is, the second millennium BC (eds. Kitchen \& Lawrence 2012:121-125, 143-145, 197f., 228-233), and those who want covenant theology and Deuteronomy to stem from the exilic times, following Wellhausen (Koch 2008). Bernard M. Levinson and Jeffrey Stackert present the history of this debate (Levinson \& Stackert 2012). There is no need to repeat it here. Proposals that the impressive similarities between Deuteronomy and the EST are not due to borrowing from the EST, but from any other Assyrian oath or treaty that was kept in Jerusalem (Radner 2006), were brought forward before the tablet had been found in Tell Tayinat. The discovery of the EST at Tell Tayinat confirms the Assyrian enforcement of this text on western vassals, and the site of its finding suggests that the oath tablet was set up for formal display inside the temple of Jerusalem (cf. Levinson \& Stackert ibid:132). Scribes working in the administration of state and temple must have passed by the cuneiform tablet every day, and some of them were certainly able to read Assyrian cuneiform script.

Firstly, this article will summarise what Esarhaddon's Succession Treaties are. Secondly, it will highlight the sophisticated structure of this Assyrian legal document that is woven together by internal links of topics and headwords, which might have caught the eye of erudite Judean scribes who studied the way the cuneiform text was composed. Thirdly, it will deal with the invocation of deities from Palestine in $\S \S 54$ and 54B that were damaged or missing in the manuscripts from Calhu, but come to the fore in the manuscript from Tell Tayinat. Thereafter, the common sequence of topics in Deuteronomy 28:20-44 and EST § 56 will be presented. Finally, the excavation data from Calhu and Tell Tayinat will be used in order to develop a thesis about the treaties' presence in the sanctuaries of Bethel and Jerusalem, and a sketch of the steps by which the whole book of Deuteronomy came into being will be offered.

\section{Esarhaddon's Succession Treaties}

These documents regulate the transition of Esarhaddon's rule over the Assyrian empire to Ashurbanibal and Shamashshum-ukin. Though the latter one was designated to become king of Babylonia, Ashurbanibal should inherit the lion's share of the empire. Manasseh, as a tribute payer and as military ally to Esarhaddon, swore several oaths of loyalty - amongst them the EST (Radner 2006; Levinson \& Stackert 2012:132)

The tablets of the EST were extraordinary due to several aspects. They were rather large, written like modern texts in such a way that the tablet had to be turned like a page, in order for the reverse to be read. On most cuneiform tablets, the scribe just continued writing when he reached the bottom of the obverse thus inscribing the lower edge and the reverse in a way that makes the script go from bottom to top on the reverse side if one turned it like a piece of paper. This difference in writing and the horizontal piercing of the tablet proves that the document was on display and not stored in an archive. Three seals of Aššur depict the images of deities. Hence, the tablet is an idol, a sort of icon (cf. EST § 35; Steymans 2003). By the act of sealing, the oath tablets were elevated to the status of tablets of destinies (Lauinger 2012:87). 


\section{The structure of Esarhaddon's Succession Treaties}

The language of Esarhaddon's Succession Treaties is poetic prose. The distribution of words shows that the stipulations are carefully structured. Certain topics appear and reappear consciously distributed throughout the text (Steymans 2000).

A curse as long as the curse of the great gods of heaven and earth in $\S 56$ is unique in the Ancient Near East (ANE). The almost identical sequence of topics in both $\S 56$ and Deuteronomy 28:20-44 is also unique (Steymans 1995). The following $\S 57$ is the oath, which the takers of the oath had to proclaim. The verb forms are in the first person plural, pointing to the collective character of subjects under Esarhaddon's rule. They swear loyalty using a collective 'we'. In line 502 of $§ 57$, the oath contains the expression 'speaking treason' (Semitic root s.r.r.): 'We will neither listen nor conceal incitement to assassinate nor listen to those who spread rumours of any evil thing, which is neither good or seemly and disloyal' (1. 501: ša amat sal.hul la dùg.ga-tu la banitu 1. 502: dabab surrāte la kinate). A similar expression occurs in line 108 of $\S 10$ : 'You will not listen to, or conceal any word which is improper or unsuitable concerning Ashurbanipal' (abutu la dùg.ga-tu la $\operatorname{sig}_{5}-t u$ la banitu). § 10 has been discovered to be a parallel to Deuteronomy 13:2-6 in line 116f., mentioning prophets as rebels by Paul-Eugen Dion (Dion 1991). In addition, § 12 demands lynching, as does Deuteronomy 13:10. Combining the observations made by Dion and Steymans on the dependence of parts of Deuteronomy 13 and 28 on the EST,
Eckart Otto argued that the author of the first edition of Deuteronomy conceived it as a loyalty oath to Yhwh (Otto 1999, 2002). Christoph Koch, an adherent of the exilic dating of any covenant theology, tried hard to dismiss the idea of direct borrowing from the EST. However, he was honest enough to admit that the parallel of dabab surrāte ( $\$ 571.502$ from sartu, pl. sarrātu or surrātu) and dibbēr sārāh (Dt 13:6 from the root s.r.h, a byform of s.r.r), as well as the identical sequence of curse topics in EST §§ 39-42 and Deuteronomy 28:25-34* witness to Assyrian influence (Koch 2008:244, 316).

In Jerusalem, the oath in $\S 57$ must have been the best-known part of the treaty, since Manasseh proclaimed it during the oath taking ceremony to which he was summoned in Niniveh, together with high ranking officials of the Assyrian empire and other vassals. During the treaty ceremony, an Assyrian scribe must have proclaimed $\S 57$ phrase by phrase, and the oath-takers repeated it together in the Assyrian language. Esarhaddon certainly made sure that the foreign affiants knew what they pledged to fulfil. This paragraph was translated into Hebrew at a certain point. It is arguable that the Judean scribes interested in Assyrian legal texts would first focus on $\S 57$, the oath sworn by their monarch. Their interest would also be focused on the curses that precede and follow the oath, and thus wander to § 56: the curse of the great gods of heaven and earth. Their eyes would also wander to certain parts of the stipulations linked with the oath through common headwords. Table 1 presents some of the links that are woven into the Assyrian text. Parallel passages in Deuteronomy are given as well.

TABLE 1: The structure of the Esarhaddon's Succession Treaty compared to equivalent topics in Deuteronomy.

\begin{tabular}{|c|c|c|c|c|}
\hline Esarhaddon's Succession Treaty & Lines & Common topic or identical formulations & Deuteronomy & Verses \\
\hline$\S 4$ 'First Commandment' & $41-61$ & $\begin{array}{l}\text { 'Do not change or alter the word of Esarhaddon, king of Assyria'; } \\
\text { To loyally help Ashurbanipal as the successor of Esarhaddon }\end{array}$ & Chapter 13 & $\begin{array}{l}1 \text { 'All I command you, do not } \\
\text { add or take away from it' }\end{array}$ \\
\hline \multicolumn{5}{|l|}{ Stipulations } \\
\hline$\S 10$ Stipulation & $108-122$ & 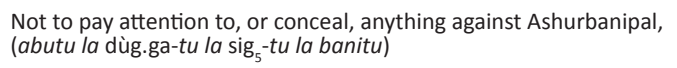 & Chapter 13 & $2-12$ \\
\hline$\S 12$ Stipulation & $130-146$ & Lynching & Chapter 13 & 10 \\
\hline$\S 14$ Stipulation & $162-172$ & To assist in suppression of revolts, let Ashurbanipal flee (ezābu-Š) & - & - \\
\hline$\S 25$ Admonition & $283-301$ & $\begin{array}{l}\text { To repeat the adê to their sons with warning of deportation: } \\
\text { 'Do not set any other king over you!' }\end{array}$ & $\begin{array}{l}\text { Chapter } 17 \\
\text { Chapter } 28\end{array}$ & $\begin{array}{l}14 f . \\
36\end{array}$ \\
\hline \multicolumn{5}{|l|}{ Curses } \\
\hline$\S 38 \mathrm{~A}$ Anu & - & Mesopotamian god of the heaven: illness & - & - \\
\hline$\S 39 \operatorname{Sin}$ & - & Mesopotamian god of the moon: skin disease & - & - \\
\hline$\S 40$ Šamaš & - & Mesopotamian god of the sun: blindness, injustice & - & - \\
\hline$\S 41$ Ninurta & - & Mesopotamian god of war: defeat & - & - \\
\hline$\S 42$ Dilbat & - & Mesopotamian god of Venus: being plundered & - & - \\
\hline$\S 52$ Gula & - & Mesopotamian goddess of healing & - & - \\
\hline$\S 53$ Sebetti & - & Left out in the manuscript of Tell Tayinat & - & - \\
\hline$\S 54$ Aramiš & - & Qarnaim, east of the Lake of Tiberias (Palestine) & - & - \\
\hline §54A Adad and Šāla of Kurba'il & - & Kurba'il, Northeastern Mesopotamia (Kurdistan) & - & - \\
\hline$\S 54 B$ Šarrat-Ekron & - & Ekron, Mediterranean coast (Palestine) & - & - \\
\hline$\S 54$ Bethel and Anat-Bethel & - & Bethel (Palestine) & - & - \\
\hline$\S 55$ Kubaba & - & Charcemish (Syria) & - & - \\
\hline \multirow[t]{3}{*}{$\S 56$ Curse } & $472-493$ & Great gods of heaven and earth & Chapter 28 & 20-44 \\
\hline & $476-479$ & Hunger (ezābu-G) & - & $20 \mathrm{~b} 21$ \\
\hline & - & Deportation of the king you have set over you & - & 36 \\
\hline \multicolumn{5}{|l|}{ Oath } \\
\hline$\S 57$ & 494-511; 501-502; [cf. §10] & ša amat sal.hul la dùg.ga-tu la banitu dabab surāte la kinate & Chapter 13 & 6 (dbr sārāh) \\
\hline \multicolumn{5}{|l|}{ 'Ceremonial’ curses } \\
\hline §§ 58-106 & $\S 63$ & Earth turned into iron, sky of bronze & Chapter 28 & 23 \\
\hline
\end{tabular}


The repetition of headwords connects certain paragraphs of the EST. The most relevant parts for all vassals were the 'first commandment' in $\S 4$ and the oath in $\S 57$. The Assyrian official who monitored the local Judean administration probably made sure that the oath was recited and translated publicly in Jerusalem according to some stipulations of the treaty.

\section{The curse section of the exemplar from Tell Tayinat}

The manuscript of the EST from Tell Tayinat preserves two additional curses, that Jacob Lauinger named $\S \S 54 \mathrm{~A}$ and B. The first one invokes the pair Adad and Šăla of Kurba'il and the second one invokes the goddess Šarrat-Ekron, the Lady of Ekron (Lauinger 2012:90f.). In addition, the curse section from Tell Tayinat enables the completion of $\S 54$, which was so damaged in the Nimrud manuscripts that it was unknown, except for the deity invoked. It has become clear now that §§ 54-55 geographically point to regions in the vicinity of Jerusalem. The series of curses runs in ms T-1808 (Lauinger ibid:113; Parpola \& Watanabe 1988):

§54 May Aramiš, lord of the city and land of Qarnê (and) lord of the city and land of Aza'i, fill you with green water.

§54A May Adad and Šãla of Kurba'il create piercing pain and ill health everywhere in your land.

§ 54B May Šarrat-Ekron make a worm fall from your insides.

§ 54C May Bethel and Anat-Bethel hand you over to the paws of a man-eating lion.

§ 55 May Kubaba, the goddess of Carchemish, put a serious venereal disease within you; may your urine drip to the ground like raindrops. (p. 49)

The curse invoking the belligerent Sebetti, § 53, is missing in $\mathrm{ms} \mathrm{T}-1808$. Hence, the sequence of curses involving Mesopotamian deities ends with Gula in $\S 52$. Then $\S 54$ geographically jumps to a region east of the river Jordan. The characteristics of god Aramiš are not known. Qarnê is the name of the Assyrian province in Transjordan, whose eponymous capital has been identified as the biblical Qarnaim, east of the Lake Tiberias (Lauinger 2012:119). The town Qarnaim/Qarnê (Šēh Sa'd) in the Bashan Mountains and its surrounding territory was under changing Israelite or Aramaic dominion during 9th century BC (Hasegawa 2012:128f.). It became an Assyrian province in 732 BC, when Tiglath-pileser III conquered Damascus (Radner 2006-2008:61).

The following curse, $\S 54 \mathrm{~A}$, geographically points to northern Mesopotamia. Kurba'il has not yet been located, but is thought to be situated near the Great Zab river, west of Arba'il and east of Guzana (Radner 2006-2008:47). It is a region where peoples deported from the Levant may have settled and it was part of a strip of territory with a mixed population of peoples speaking Assyrian and Aramaic (Kinnier Wilson 1962:99). Salmanassar III dedicated a statue of himself to Adad of Kurba'il, which bears an inscription praising this weather god in terms that fit well for Phoenician and Israelite Ba'al, Aramaic Hadad, as well as Hittite Tarhunta, Hurrian and Uratean Tešup:

[Adad of Kurba'il] bears the Sacred Whip [called] 'Lasher of the Seas', who [...] makes rain to fall, the lightning flash, and the vegetation to grow, at whose voice the mountains rock and the seas swell. (1l. 4-6; cf. Kinnier Wilson 1962:95)

Rainfall made agriculture possible in the region of Kurba'il. This Adad has a character quite different from the Adad invoked in $\S 47$ line 440 of the EST - the one who brings floods necessary for agriculture based on irrigation. There is not much coast in Mesopotamia. The sea on which Adad of Kurba'il lashes his lightning is Lake Van and Lake Urmia (Tešup's domain), as well as the Mediterranean Sea (Ba'al and Hadad's domain). In addition, Salmanassar III praises Adad of Kurba'il for 'bringing the kings, my enemies, to bow at my feet' (1.36), including those of Tyre and Sidon, as well as Jehu, son of Omri (1l. 29f., Kinnier Wilson 1962:96). Hence, it becomes clear why $\S 54 \mathrm{~A}$ of the EST invokes Adad and Šala of Kurba'il in a context of deities located in the Levant. This Adad is the Assyrian manifestation of the weather god, venerated as Ba'al, Hadad or Tešup by the peoples of the Levant and Armenia, and submitting them to Aššur's rule.

Geographically, § 54B almost touches the Mediterranean seashore by invoking Šarrat-Ekron, a goddess identified with Ptgyh, the Lady of Ekron (Lauinger 2012:119). In 672 BC, Ekron was an Assyrian vassal, not an Assyrian province. If the goddess of Ekron appears in a curse, it is safe to conclude that there was a copy of the oath tablet in Ekron. If Assyria's vassal at Ekron (Tel Miqne) received a copy of the EST, then even more certainly did Assyria's vassal at Jerusalem - the relation between the two Assyrian vassal states being delicate due to Hezekiah's adventure with Padi, king of Ekron.

If the provincial capital Kullania was in possession of a copy of the EST, temples in Qarnê/Qarnaim and Samaria, capitals of Assyrians provinces, must equally have had copies on display.

EST § 54C is also of Levantine origin. The curse exists identically in Esarhaddon's vassal treaty with Baal of Tyre and invokes Bethel and Anat-Bethel. All deities of §§ 54-55 are located geographically (Qarnê and Aza'i, Kurba'il, Ekron and Charchemish), except for Bethel and Anat-Bethel. Did these deities not have a special sanctuary? Perhaps the name of the deity itself alluded to a sanctuary, namely Bethel (Bētīn), $16 \mathrm{~km}$ north of Jerusalem. Isaiah 48:13 connects the deity Bethel with the temple of Bethel in such a way that both the veneration of the god (Bethel) as well as the veneration of God (Jhwh) in a temple outside Jerusalem may be the cause of calamity (Koenen 2006). The curses depict the Levantine deities from an Assyrian point of view. The weather god is called Adad of Kurba'il, not Baal-samême, Baal-malagê or Baal-șaphôn as in the vassal treaty with Baal of Tyre. Ptgyh of Ekron does not appear under her name, but under the Assyrian title šarratu (queen). It is arguable that the Israelites identified Bethel and Jhwh by means of 'religious cross-fertilization' (Niehr 2003:189). If the Assyrians conceived Bethel as one manifestation of El, Bethel may also have been outsiders' way to allude to the deity venerated in the temple of Jerusalem. Is it mere coincidence that Yhwh, especially the one manifest in Israel, had the reputation of punishing by sending lions, as did Bethel and Anat-Bethel (cf. Strawn 2005)? 
The curses linked to locations in the Levant are separated from $\S 56$, the model for Deuteronomy $28: 20-44$, by $\S 55$, the curse of Kubaba of Carchemish (Is 10:9; Jr 46:2; 2 Chr 35:20) a town on the frontier between Syria and Turkey on the West bank of Euphrates river $100 \mathrm{~km}$ northeast of Aleppo. Sargon II defeated Pisiri, the last king of Charchemish, in 717 BC.

\section{Deuteronomy 28:20-44 and Esarhaddon's Succession Treaties $\S 56$}

This section highlights the parallels between Deuteronomy 28:20-44 and EST § 56, the curse of the great gods. Although lists comparing curse motifs in extra biblical texts with Deuteronomy 28 present a lot of motif parallels, a careful look at such lists shows that the paralleling of motifs destroys the sequence of elements in one text in order to fit it to the sequence of the other (eds. Kitchen \& Lawrence 2012:244, Dt 1-32 being number 83 in their counting of ANE treaties). In Deuteronomy 28:20-44 and EST § 56, however, the sequence of motifs is identical. In only two cases does a topic appear at a slightly different position, and in both these cases one can explain the difference as a deliberate scribal arrangement.

Apart from the identical sequence of topics in both curses, there is an astounding parallel regarding the syntax. Curses invoking Yhwh or the gods as subjects causing calamity, alternate with curses in which natural forces are the subjects, or sentences that just describe the result of the preceding curse. In Deuteronomy 28:20-44 and EST § 56, these alternations occur at parallel positions.

There is still another syntactical parallel between the Assyrian and the Hebrew text. The curses invoking the divinity are optative sentences. In Assyrian, precative verbal forms mark the optative. In Hebrew, yiqtol- $x$ formations mark the optative. Although most English translations render Deuteronomy 28:20-44 as indicative, the Hebrew text alternates between invocations of Yhwh that concede to him the option of punishing in optative yiqtol- $x$, and sections in the indicative dealing with the consequences of Yhwh's punishments or the harmful effect of natural forces. The following translation will indicate an optative sentence by using 'may'. A similar comparison has previously been published (Steymans 1995). The comparison presented here has been amended to highlight vocabulary and syntactical features common to both texts.

There is not much need for the diachronic separation in Deuteronomy 28:20-44. Three verses show elements of later elaboration.

\section{Deuteronomy 28:20c}

Deuteronomy 28: 20c: '[because of your evildoing] in forsaking $\mathrm{Me}^{\prime}$.

This ending of the first curse reads in Hebrew: mipp $n \hat{e}$ rō $m a^{c} a l e l \hat{e}-k \bar{a}{ }^{\prime} a \check{s} e r{ }^{c a} z a b t \bar{a}-n \hat{\imath}$. The three words at the beginning do not appear elsewhere in Deuteronomy, however, they appear in Jeremiah three times (Jr 4:4; 21:12; 44:22). Since the curse section following in Deuteronomy 28:45-62 has a lot of links to Jeremiah, it is safe to suggest that the scribe who added the curses after verse 45 also added mippen $n \hat{e}$ rō ${ }^{a c} m a^{c}$ alelê- $k \bar{a}$ in order to point to the prophetic language (cf. Is 1:16; Hs 9:15) right at the beginning and prepare for the following links with Jeremiah. Nowhere else does the relative clause ${ }^{\prime a}{ }_{S}{ }^{2}{ }^{c a} z a b t \bar{a}-n \hat{\imath}$ follow rō $\bar{o}^{a c} m a^{c}$ alelêe-ka in the Hebrew Bible. There is 'a $a$ ser ${ }^{c a} z \bar{a} b \hat{u}-n \hat{\imath}$ in Jeremiah 1:16 and ka'ǎser cazabtem 'ôtî in Jeremiah 5:19. The relative clause in Jeremiah expressing that the people leave (forsake) Yhwh differs from the one in Deuteronomy 28:20. In addition, it does not occur in context with mippenê rōo $m a^{c}$ alelê-kā in Jeremiah. In Deuteronomy, the verb ${ }^{c} . z . b$ is linked to the Levites in Deuteronomy 12:19 and 14:27.

Deuteronomy 29:25 quotes the statements of people passing by giving the reason for the disaster that befell Israel: 'Because they forsook the covenant of Yhwh, the God of their fathers' ('al 'ǎser 'āżeb̂u 'et berît Yhwh 'xlōhê 'abōtām). Deuteronomy 31 quotes the words of God, predicting that his people:

... will begin to prostitue themselves to the foreign gods in their midst, the gods of the land into which they are going; they will forsake me [wa- $\left.{ }^{c a} z \bar{a} b a-n \hat{\imath}\right]$, and break my covenant, which I have made with them. (Dt 31:16)

It is important to notice that Deuteronomy 28:20 is the first occurrence in Deuteronomy where the verb ${ }^{c} . z . b$ means 'leaving or forsaking Yhwh', and that this meaning is taken up in Deuteronomy 29 and 31. Further use of the verb ${ }^{c} . z . b$ speaks about Yhwh leaving or abandoning his people (Dt 31:6, $8,16,17 ; 32: 26)$. Hence, ${ }^{c} . z . b$ only means leaving Yhwh as a form of disobedience in Deuteronomy 28:20, the first verse of the curse section, and then in two quotations, namely in the words of other people (Dt 29:25) and of Yhwh (Dt 31:16). Prophetic language uses the verb in a similar sense, however, never in the context of $r \bar{o}^{a c} m a^{c} a l e l \hat{e}-k \bar{a}$.

The verb ezābu, the Assyrian equivalent of Hebrew ${ }^{c} . z . b$, occurs in line 479 of $\S 56$ with food and water as subjects. The only other occurrence of the verb in the EST is in line 172 of $\S 14$, a stipulation closely linked to the whole treaty's 'first commandment' in $\S 4$ through the word repetition of a.šà 'field' (1. 49, 1. 165), nașāru 'protect' (1. 50, 1. 168), uru 'city' (1. 49, 1. 166), gammurtu 'totality' (1. 53, 1. 169), libbu 'heart' (1. 51, $53,1.169)$. The treaty's addressees must protect Assurbanipal in country (field) and town (city), and advise him in total truth of their heart according to $\S 4$. Then $\S 14$, demanding them to protect Assurbanibal, repeats this order in case of a rebellion. The stipulation ends: 'You shall Assurbanibal [...] let escape [leave]' [the dangerous situation tušezabā-ni-ni, ezābu-causative Š-stem].

Without claiming to be able to prove it, the verb ${ }^{c} . z . b$ in verse 20c may have been inspired by the EST. The verb is rare in Deuteronomy and the EST, but it is existent in $\S 56$ and the important stipulation of $\S 14$ - and in Deuteronomy 28, it may be the relict of the conditional clause that opened the curse section in the Judean loyalty oath. The Judean scribe reversed the main offence against the overlord, using the same verb. As regards Assurbanibal, the main offence is not 
to let him leave (= rescue him from) any dangerous situation. As regards Yhwh, the main offence is to leave (= forsake) him in disobedience. Thus, the curse section of the Judean loyalty oath might have begun with something like: 'If you

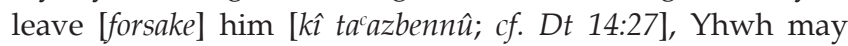
send on you curse', picking up the conjunction kî of most conditional laws in Deuteronomy. When DtrL, a pre-exilic scribe (Braulik 2011; Lohfink 1997, 2000), added the blessing of Deuteronomy 28 to his account of a covenant in Moab and the conquest of the land - starting with the barruk $k$-formulas (Dt 28:3-5) together with the corresponding 'ârûr-formulas (Dt 28:16-19) and the alternative introductions of blessing and curse in Deuteronomy 28:1f. and 15 - the conditional clause $k \hat{\imath}$ tacazbenn $\hat{u}$ was transferred to the end of verse 20 and the verb changed into perfect $k \hat{\imath}^{c}$ azabtô (cf. Dt 13:11; 22:2, i.e. the taw moved from the front of the verbal form to its end and the nun energicum was deleted). A later scribe inserted the allusion to Jeremiah mipp $n \hat{e} r \bar{o}^{a c} m a^{c} a l e l \hat{e}-k \bar{a}$ and replaced $k \hat{\imath}$ by ${ }^{\prime}{ }^{\prime} \breve{S} e r$. The first person pronoun present in the Masoretic text today may be a technical mistake made by one scribe during the transmission process confusing waw with nun, letters that look similar in the Paleo-Hebrew alphabet as they do in the Hebrew 'square script', because he knew Deuteronomy by heart and was influenced by the first person pronouns in Deuteronomy 29:15 and 31:16. One Septuagint manuscript has the third person pronoun, and Old Latin has 'because you have forsaken the Lord'.

\section{Deuteronomy 28:21a}

Deuteronomy 28:21aI: 'until he has put an end to you [on the soil, 21aR you are entering to possess]'.

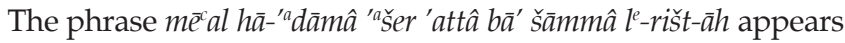
similarly in Deuteronomy 12:1, 21:1, 30:18, 31:13 and 32:47. However, it appears absolutely identically in Deuteronomy 28:63. Verse 63 starts with a small poem later inserted in the curse section (Steymans 1995). The scribe who added the poem also added the phrase in verse 21 in order to bracket his addition in Deuteronomy 28:63-65 with the section Deuteronomy 28:20-44. Since a previous scribe already added to verse 20, the first verse of the oldest part of the curse section, this later scribe added to the second verse of this section, namely verse 21 .

\section{Deuteronomy 28:36b}

Deuteronomy 28:36b: 'There you will worship other gods, gods of wood and stone. [37a] You will become a horror, a proverb and a byword among all the peoples, $[a R]$ where the Lord will drive you'.

Verses $36 \mathrm{~b}$ and 37 assess worshipping of other gods as punishment, and not as sin. The same idea is present in Deuteronomy 4:28, 28:64 and 29:17. Thus, this passage may be an addition by the same scribe who added his poem in Deuteronomy 28:63-65.

Italics mark the common vocabulary and syntactical parallels in Deuteronomy 28 and the EST. The Assyrian and Hebrew language only sometimes use common Semitic roots in exactly the same meaning. Identical or semantically corresponding Semitic roots are put in parentheses. Every sentence starts a new line. The Bible text indicates main and subordinate clauses according to Richter (1991): 'I' meaning infinitive and ' $R$ ' meaning relative clause. The Assyrian text follows Parpola and Watanabe (1988).

Since both texts are rather long, they are divided into sections for convenience. The texts are arranged in tables (Tables 2-9) with three columns. Two columns parallel Deuteronomy 28: 20-44 with EST § 56, model for the sequential arrangement of topics. The third column gives the text of other inserted curse paragraphs, because the scribe composing Deuteronomy 28:20-44 considered their topic fitting to the topic indicated by $\S 56$.

Both curse sequences begin with the divinity as subject of the clause and the keyword curse taken from the Semitic root '.r.r. (Table 2). The predicate of line 474 mahāṣu [to strike] may have been the inspiration for the series of curses using the predicate n.k.h-Hiphil [to strike] in Deuteronomy 28:22, 27, 28 and 35 (Table 4, 7f.).

The divinities are the subject of the syntax of the curse. The ending of life is the common topic, in Hebrew it is expressed with an infinitive of k.l.h, and in Akkadian with the Mesopotamian vegetable metaphor of 'rooting out' (Table 3). Pestilence is the concluding illness in EST, line 480 of the

TABLE 2: Divine curse using the semitic root '.r.r.

\begin{tabular}{|c|c|c|}
\hline Deuteronomy 28 & EST § 56 & EST other paragraphs \\
\hline Jhwh curses (me'ērâ) & The great gods curse (arratu) & - \\
\hline $\begin{array}{l}\text { 20a May Yhwh send on you curse, confusion and rebuke in all the enterprises } \\
\text { b you put your hand to, } \\
\text { bl until you are destroyed } \\
\text { bl2 and come to sudden ruin } \\
\text { c [because of the your evildoing] in forsaking Me. }\end{array}$ & $\begin{array}{l}472 \text { May all the grea[t go]ds of heaven and earth who inhabit the universe } \\
\text { and are mentioned by name in this tablet, } \\
474 \text { strike you, look at you in anger, } \\
475 \text { curse you grimly with a } \\
\text { painful curse. }\end{array}$ & - \\
\hline
\end{tabular}

EST, Esarhaddon's Succession Treaty.

TABLE 3: The deity brings existance to a termination.

\begin{tabular}{ll}
\hline Pestilence as a heading; Jhwh ends life (k.l.h) & The gods root out (nasähu) \\
$\begin{array}{ll}\text { 21a The Lord make pestilence cling to you } \\
\text { 21al until he has put an end to you [on the soil, } \\
\text { 21aR you are entering to possess]. }\end{array}$ & $\begin{array}{l}476 \text { Above, may they root you out; below, in the earth, may they } \\
\text { make your ghost thirst for water. }\end{array}$ \\
\hline
\end{tabular}

g to possess].

EST, Esarhaddon's Succession Treaty. 
following section of $\S 56$ (Table 5). This section is marked in line 479 by a shift of the subject from divinity to natural entities. The Hebrew scribe transferred the topic of pestilence to verse 21, as the beginning of a series of illnesses unfolded in verse 22 (Table 4). Thus, he makes pestilence a heading, whereas it was a conclusion in the Assyrian text. The Hebrew scribe did not adopt the Mesopotamian concern for the ghost of the dead in accordance to the general reluctance of the Hebrew Bible in dealing with the afterlife.

The Judean scribe took up the verb 'to strike' from the first curse of $\S 56$ together with the divine subject. Then he followed the shift from divine subject to natural entity by making the diseases the actors of the chasing, as are shade and daylight in $\S 56$ (Table 4 ).

The headwords 'food' and 'water', as well as 'want', 'famine' and 'hunger' in $\S 56$ provide the topic for this section. The Assyrian curse of $\S 56$ starts with entities (food and water) as subject of the sentence. The Judean scribe follows this by making sky and ground the subjects of the Hebrew sentences. He elaborates on the topic by inserting a curse from $\S 63$. His attention was called to this curse whilst reading the EST through the co-occurrence of 'ground' and 'sky' together with 'the great gods [...] who are mentioned by name in this tablet', which is similar to the beginning of $\S 56$. The word kaqquru [ground, earth] is written in syllables in $\S 63$, indicating the Assyrian pronunciation of the logogram ki.tim in $\S 56$ (Parpola \& Watanabe 1988:92, sub kaqquru). Hence, when read aloud there is a link (Table 5).

Only one exemplar from Calhu has a dividing line between lines 529 and 530, thus counting a $\S 63$ and a $\S 64$, as do the modern editions. All other manuscripts from Calhu, as well as the tablet from Tell Tayinat, present lines 526-533 $(=\S 63+64)$ as one single paragraph (Lauinger 2012:120). It is one single curse and the Judean scribe was right in taking it up completely. However, he changed the sequence of the similes. The EST lists the metals in a sequence of decreasing hardness - from iron to lead - in the following $§ 65$. By doing so, the Assyrian text inverts the common sequence of heaven and earth to ground and sky. The Hebrew scribe changed the sequence to heaven and earth, but kept the comparison of sky with bronze and ground with iron. Both curses change their subjects. EST $\S 63$ starts with the gods who turn the ground into iron. The subjects of the next sentence are natural entities, namely rain, dew and burning coals. Mixing both Assyrian syntactical structures, the one with divine subject in lines 526-529 and those with natural elements as subject in line 530 (§ 63) and lines 479 and 480 (§ 56), the Hebrew text starts with sky and ground as subjects, following the vocabulary of lines 526-529 and the syntax of lines 479 and 480. Then Yhwh is the subject causing harmful rain, following the syntax of lines 526-529, where the gods are the subject. Military defeat is the topic of $\S 65$, a curse using the simile of lead in order to denote military weakness. The sons and daughters taken by the hand by their fleeing parents link this paragraph to the young women and young men of $\S 56$, whose bodies are mutilated in the squares of Assur before the eyes of their parents, relatives and neighbours.

EST § 56 does not describe military defeat, however, the scene of line 481f. presupposes deportation because the mutilation of bodies takes place in the city of Assur. This might be the finale of a triumphal procession in which captives of rebellious countries were carried through the streets of Assur. Thus, the topic of military defeat only alluded to in $\S 56$ and the topic of corpses being food for animals then expressed in $\S 56$,

TABLE 4: Natural forces chase the cursed humans.

\begin{tabular}{ll}
\hline Illnesses chase & Shade and daylight chase \\
\hline $\begin{array}{l}\text { 22a The Lord strike you with consumption, with fever and inflammation, with } \\
\text { scorching }\end{array}$ & $\begin{array}{l}\text { Mat other paragraphs } \\
\begin{array}{l}\text { heand drought, with blight and mildew, } \\
\text { b they will chase you }\end{array}\end{array}$ \\
\hline
\end{tabular}

EST, Esarhaddon's Succession Treaty.

TABLE 5: Lack of food due to the impossibility of agriculture.

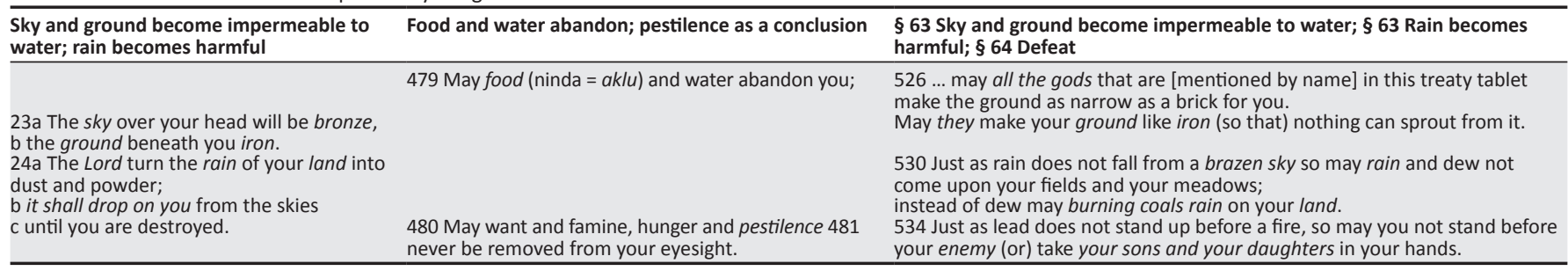

TABLE 6: The results of military defeat using the semitic root '.k.I. 
probably has lead the eye of the Judean scribe to $\S 41$ : the curse invoking Ninurta, which clearly speaks of defeat. He conflated $\S 41$ and $\S 56$ in order to create verse $25 \mathrm{f}$. He began his curse by invoking Yhwh instead of Ninurta and expressing defeat. He kept the Semitic root '.k.l present as verbal form in

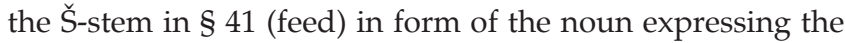
effect of the curse in verse 26a (food). In addition, he changed the subject. The addressees of the curse are the subject of verse 26 , as are the addressees' young women and men in $\S 56$. The Hebrew curse continues to have the corpses being the subject of verse 26, whereas the Assyrian one of $\S 56$ has the earth as subject. Both curses share the topic of refused burial. Both curses have an international flavour by becoming a horror to foreign kingdoms, as well as a spectacle in the capital of the multi-ethnic Assyrian empire. The combination of birds and beasts in verse 26 conflates the birds (eagle and vulture) of $\S 41$ and the beasts (dog and pig) of $\S 56$ (Table 6).

It has long been noticed that Deuteronomy 28:27-29 parallel the Sin and Shamash curses of Assyrian treaties. However, being aware of the topic indicated by $\S 56$ line 485 , one realises that the Judean scribe rearranged the complete sequence of Anu-Venus curses, that is $\S \S 38 \mathrm{~A}-42$, in order to elaborate on the topics he found in $\$ 56$. The headwords 'sighing' and 'sleeplessness' link § 56 with the Anu-curse in § 38A, and the skin disease rendered 'leprosy' links the Sin-curse § 39 with the skin disease translated 'scurvy' in Deuteronomy 28:27. Loss of eyesight (blindness), as well as darkness, link Deuteronomy 28:29 with $\S 56$ and the Shamash-curse in $\S 40$ (Table 7).
The subjects change. Verse 27 starts with the divinity as subject, as do $\S \S 38 \mathrm{~A}-40$. Verse 29 shifts to the addressees as subject, as do the Sin-curse (roam in the desert) and the Shamash-curse (walk about). Both the biblical and the Assyrian curses focus on the desperate way the people move (grope about).

Having elaborated on the topic of military defeat by using imagery of $\S 41$ to create Deuteronomy 28:25, the Judean scribe now elaborates on $\S 42$. This curse invokes Venus, a manifestation of Ishtar, and offers the headwords 'eyes' taken up in verses 32 and 34, 'lying' as a metaphor for sexual intercourse and rape taken up in verse 30, 'sons' taken up in verse 32, and 'enemy' taken up in verse 31. The loss of possession to spoiling soldiers is the common topic. The metaphor of an irresistible flood in $\S 56$ also denotes military defeat. The Biblical text is enriched by futility curses that add the topics house and vineyard, as well as curses that focus on cattle. It is not before Deuteronomy 28:31e and 32a that the Assyrian headwords are taken up again. The Venus curse focuses on the impossibility of transferring property as a heritage to the next generation. There is no deportation from the land. However, the enemy is in the land and takes all goods. The biblical curse goes one step further in making the sons themselves a chattel to be taken by the spoiling army. Their parents remain in their land, consumed by the yearning for their children (Table 8).

The return to illness in Deuteronomy 28:34 and 35 is inspired by the term 'ill' in $\S 56$. The Tell Fekhariye inscription reveals that the rendering of curses that are mere invocations in

TABLE 7: The curse motifs of Anu, Sin, and Šamaš.

Illness; skin disease; confusion; you will grope in Your days will be dark; depression the dark; oppression

27a May Yhwh strike you with the boils of Egypt and with tumours, scurvy and itch,

$b$ and you cannot be cured.

28a May Yhwh strike you with madness, blindness

and confusion of mind.

IIIness § 38A Anu; skin disease § 39 Sin; confusion § 40 Šamaš

29a At midday you will grope about

$\mathrm{b}$ as a blind person gropes in the dark.

c You will not prosper in your ways;

c You will not prosper in your ways;
$\mathrm{d}$ and day after day (kol hay-yāmîm) you will be May your life end in sigh [ing and slee]plessness.

485 May your days (ūmī-kunu) be dark and your

years dim, may darkness which is not to be brightened be declared as your fate.

418A May Anu, king of the gods, let disease, sighing, malaria, sleeplessness, worries and ill health rain upon all your houses. 419 May Sin, the brightness of heaven and earth, clothe you with leprosy and forbid your entering into the presence of the gods or king.

Roam the desert like the wild ass and the gazelle.

422 May Šamaš, the light of heaven and earth, not judge you justly. May he remove your eyesight. Walk about in darkness!

oppressed and robbed,

c with no one to rescue you.

TABLE 8: The motif of plundering enemies followed by baleful wishes.

\section{Wife taken by another man}

Enemy invasion expressed in the metaphor of a flood

Wife taken by another man § 42; Venus

30a You will be engaged to a woman,

$b$ but another will lie with her (rape her).

c You will build a house,

d but you will not live in it

e You will plant a vineyard,

f but you will not even begin to enjoy its fruit.

31 a Your ox will be slaughtered before your eyes,

b but you cannot eat of it.

c Your donkey will be seized in front of you

c Your donkey will be seized in

$\mathrm{d}$ and will not be returned.

e Your sheep will be given to your

$\mathrm{f}$ and no one will rescue them.
$32 \mathrm{a}$ Your sons and daughters will be given to a strange ('ahēr) nation
$\mathrm{b}$ and your eyes will watch and wear out for them day after day,

$c$ powerless to lift a hand.

33a A people

aR that you do not know

a will eat the produce of your land and labor,

$\mathrm{b}$ and you will abused and downtrodden all your days.

34a The sights

aR you see

a will drive you mad.

35a May Yhwh strike your knees and thighs with painful boils

aR that cannot be cured

a spreading from the soles of your feet to the top of your head

488 May an irresistible flood come up (Iillâ-ma) from the earth and devastate you;

may your sons not take possession of you house,

may a strange (ahû) enemy divide your goods. 428 May Venus, the brightest of the stars,
before your eyes make your wives lie in the lap of your enemy;

may anything good be forbidden to you,

may anything ill be your share; 
TABLE 9: Deportation and appointment of a king.

\begin{tabular}{|c|c|c|}
\hline Deuteronomy 28; Deportation of the people and its king & EST § 56 & $\begin{array}{l}\text { EST other paragraphs; } \S 25 \text { Admonition of parents: Deportation of the people due to } \\
\text { the appointment of another king }\end{array}$ \\
\hline $\begin{array}{l}\text { 36a May Yhwh make you and the king } \\
\text { aR you have set over you go a to a nation } \\
\text { aR2 unknown to you or your ancestors. } \\
\text { [b There you will worship other gods, gods of wood and stone. } \\
\text { 37a You will become a horror, a proverb and a byword among all the peoples } \\
\text { aR where the Lord will drive you.] }\end{array}$ & - & $\begin{array}{l}288 \text { You shall speak to your sons and grandsons, your seed and your seed's seed which } \\
\text { shall be born in the future, and give them order as follows: } \\
\text { 'Guard this treaty. } \\
\text { Do not sin against your treaty } \\
293 \text { do not annihilate yourselves, } \\
294 \text { do not turn your land over to destruction and your people to deportation... } \\
\text { 301 Do not set any other king or any other lord over you.' }\end{array}$ \\
\hline
\end{tabular}

EST, Esarhaddon's Succession Treaty.

Assyrian as futility curses in a West-Semitic text is not uncommon (Steymans 1995:156-161, 181-185).

There is no curse in EST that deals with deportation. Deportation, however, is the topic of $\S 25$, an admonition that the oath-takers must enounce. Thus, Judeans who were bound by the EST had to say this to their children. Any Judean scribe must have been aware of this admonition. The headword 'son' links it to the topic of several curses of the EST. The most striking correspondence between Deuteronomy 28:36 and EST $\S 25$ is the combination of setting a king over oneself and deportation (Table 9).

After the topic 'lack of food' in verse 26 in correspondence to line 479 , the fact that the topic reappears with the root '.k.l 'to eat' in verse 39 and line 490 is a further indication of the common structure of both curse sections. Another identical root connects both texts, namely c.l.h [to come up, rise]. In $\S 56$, the root occurs in line 489 with the metaphor of a flood that symbolises enemies. In Deuteronomy 28, the root occurs three times in verse 43 , turning the stranger (a person to be cared for according to the biblical law) into an enemy. The Judean scribe elaborated on the topics given in $\S 56$ by creating futility curses. He kept the sequence of food, drink, and then ointment. However, he discarded clothing and repeated deportation of sons and daughters instead. The last line of $\S 56$ lists three types of spirits that haunt the dwelling places. The Assyrian verb hĩaru means 'to choose, to select', and exists also in the noun hă'iru/hāmiru/hāwiru [spouse]. The verb can mean 'to marry'. The spirits are not evil per se they may even have protective power (Wiggermann 1992:69, 96, 218f., 221). The point being made in both the Assyrian and the biblical curse is that entities that are not harmful in general and must be protected (as the stranger in the Bible) or may be protecting forces (as the spirits in ANE belief) turn out to be harmful and threaten the intimate space where one dwells ('in your midst, your houses') (Table 10).

\section{Esarhaddon's Succession Treaties on display in Temple Buildings}

This section draws some conclusions from the excavation reports from Nimrud and Tell Tayinat as to how the EST were accessible to scribes, temple personnel or even a larger public in Jerusalem.

\section{Calhu or Nimrud}

Ezida was the traditional name of any great complex of buildings that comprised the Nabu Temple (Oates 1957).
TABLE 10: Deprivation of subsistance and home.

\begin{tabular}{|c|c|}
\hline Food - drink - oil - foreign power in midst of the land & $\begin{array}{l}\text { Food - drink - oil - foreign } \\
\text { power in midst of the house }\end{array}$ \\
\hline $\begin{array}{l}\text { 38a You will take much seed out to the field } \\
\text { b but you will harvest little, } \\
\text { c because locusts will devour it. } \\
\text { 39a You will plant vineyards and cultivate them }\end{array}$ & $\begin{array}{l}\text { may tar and pitch be your } \\
\text { food (mäkalä-kunu); }\end{array}$ \\
\hline $\begin{array}{l}\text { b but you will not drink the wine or store (grapes), } \\
\text { c because worms will feed (tō'kel-enn-û) on them. } \\
\text { 40a You will have olive trees throughout your country }\end{array}$ & $\begin{array}{l}491 \text { may urine of an ass be } \\
\text { your drink, }\end{array}$ \\
\hline $\begin{array}{l}\text { b but you will not use the oil, } \\
\text { c because the olives will drop off. } \\
41 \text { a You will beget sons and daughters } \\
\text { b but they will not remain with you, } \\
\text { c because they will go into captivity. }\end{array}$ & $\begin{array}{l}\text { may naphtha be your } \\
\text { ointment, }\end{array}$ \\
\hline $\begin{array}{l}\text { 42a Locusts will take over all your trees and the crops } \\
\text { of your land. } \\
43 \text { a The stranger } \\
\text { aR who resides in your midst } \\
\text { a will rise above you higher and higher ( } y a^{c a} l e h{ }^{c} \bar{a} l \hat{e}=\underline{k} \bar{a} \\
\left.m a^{c} l \hat{a} m \bar{a}^{c e} l \hat{a}\right) \text {, } \\
\text { b but you will sink lower and lower. } \\
44 \text { a He will lend to you, } \\
\text { b but you will not lend to them. } \\
\text { c He will be the head, } \\
\text { d but you will be the tail. }\end{array}$ & $\begin{array}{l}492 \text { may duckweed from the } \\
\text { river be your covering. } \\
493 \text { May demon, devil and } \\
\text { evil spirit select your houses. }\end{array}$ \\
\hline
\end{tabular}

The place in which the EST was discovered was a hall in the northern wing of the Ezida. This hall appears to have been a throne room in which the statue of the god Nabu came to rest for some days before passing out to his country temple during the akitu festival. At one end of the room there was a stepped dais on which the throne must once have stood. In front of it there was a pair of stone lines, which may perhaps have marked the resting place for the god's statue. Figure 2 indicates where the tablets were found smashed and burnt in hundreds of fragments. They had been deliberately mutilated when Nimrud was finally sacked, probably in 612 BC (Mallowan 1958:i). Smashing of cuneiform tablets was one of the plundering soldiers' amusements. The throne room, being occasionally used as a resting place for god Nabu, was a sacred room, a sort of chapel. The EST tablets were in all likelihood on display in this room.

The oath takers mentioned in these copies were vassals from the east of the Assyrian empire, peoples living on the ranges and in the valleys of the Zagros Mountains. They were famous for horse breading. The Ezida of Calhu was the administrative centre of the cavalry of the whole Assyrian empire. The vassal people mentioned in the Calhu tablets probably came to this temple repeatedly in order to deliver horses as a tribute and may have been lead to the throne room where the EST tablets were on display in order to renew their loyalty oath (Steymans 2004, 2006:342-344). Their copies of the EST may have been kept in Calhu and not been given to them, because they lived in tents and had no temple buildings. The tablet of the oath is a tablet of Aššur, bearing the seal of Aššur, and had to be treated like a god, 


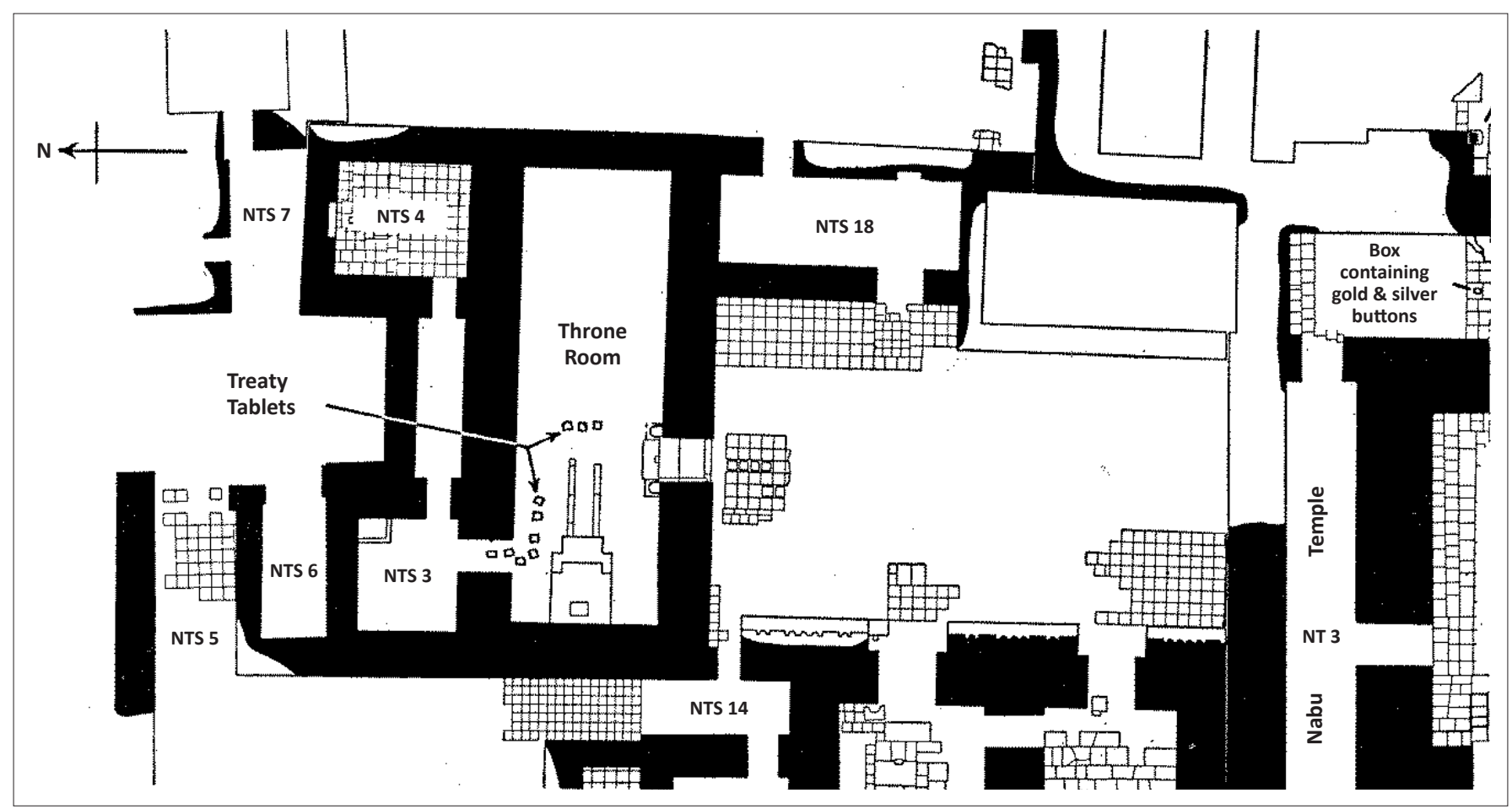

Source: Wiseman, D.J., 1958, 'The Vassal-Treaties of Esarhaddon', Iraq 20, 2, Figure 1

The arrow going out from 'Treaty Trablets' indicates where the smashed 8-11 copies of the Esarhaddon's Succession Treaty previously on display in the Throne Room were scattered on the floor. FIGURE 2: Map of the throne room in the Nabu temple at Calhu.

that is, the idol of the divinity or a holy icon. The Assyrians would hardly have transmitted this holy icon of the oath tablet to semi-nomadic vassals who could not guarantee proper safekeeping and display at home.

The Tell Tayinat manuscript helps to complete the text of $\S 35$, which was damaged in the Calhu manuscripts, and enables us to better understand how the Assyrians conceived the oath tablet and its binding force. EST § 35 runs (Lauinger 2012):

Whoever changes, neglects, violates, or voids the oath of this tablet [and] transgresses against the father, the lord, [and] the adê of the great gods

and breaks their entire oath,

or whoever discards this adê-tablet, a tablet of Aššur, king of the gods, and the great gods, my lords,

or whoever removes the statue of Esarhaddon, king of Assyria, the statue of Assurbanipal, the great crown prince designate, or the statue[s] of his brothers [and] his sons which are over him -

- you will guard like your god this sealed tablet of the great ruler on which is written the adê of Assurbanipal, the great crown prince designate, the son of Esarhaddon, king of Assyria, your lord, which is sealed with the seal of Aššur, king of the gods, and which is set up before you. (p. 112)

It now becomes clear that $\S 35$ together with the following $\S 36$ is the introduction to the standard curse section $\$ \S 37-56$. The introduction begins with indirect question clause (whoever) and points to the integrity of the tablet itself (change, violate), like $\S 36$ (remove, consign to fire, throw into water, bury, destroy, annihilate, deface). EST § 35 also demands obedience to the stipulations (neglect, void, transgress, break the oath), like $\S 58$ ( $\sin$ ), which is the introduction of the ceremonial curse section (\$§ 59-106). Thus, the idea drawn from the incomplete texts at hand before the Tell Tayinat manuscript was found, that is, that the first curse section protects the integrity of the tablet and the second one punishes disobedience, can be dismissed. Actually, the first curse section also focuses on disobedience.

\section{Tell Tayinat}

The ruins of a Neo-Assyrian temple formed part of a larger sacred precinct, which was constructed as part of an Assyrian effort to transform the former Syro-Hittite royal city of Kunulua/Kunalia into the administrative capital of an Assyrian imperial province (Harrison \& Osborne 2012:125). Modifications and additions to building XVI, the temple where the EST tablet was excavated, belong to at least two primary phases of construction. The Tayinat temples belong to the architectural tradition of the temple in antis, which is indigenous to West Syria and the Levant. The Hieroglyphic Luwian fragments found in association with these buildings furnish evidence that they were constructed as Syro-Hittite sanctuaries sometime in the 8th or 9th centuries BC. In 738 BC, Tiglath-pileser III took Kullania (Radner 2006-2008:61). In the late 8 th, early 7 th century $\mathrm{BC}$, both buildings were renovated and incorporated into an Assyrian religious complex (Harrison \& Osborne ibid:133, 139). Figure 3 depicts the finding spot of the EST tablet T-1801. When the temple collapsed due to fire, the tablet fell from its stand onto the floor at the left side of a podium in the inner sanctum. It had been suspended on the stand in such a way that, when walking around the stand, the writing could be read on the obverse and the reverse. On the right side of the podium, a mud-brick installation was found, probably an altar. Being an idol of Aššur, as seen from § 35, the inner sanctum of the temple was the appropriate place to keep the treaty tablet. 


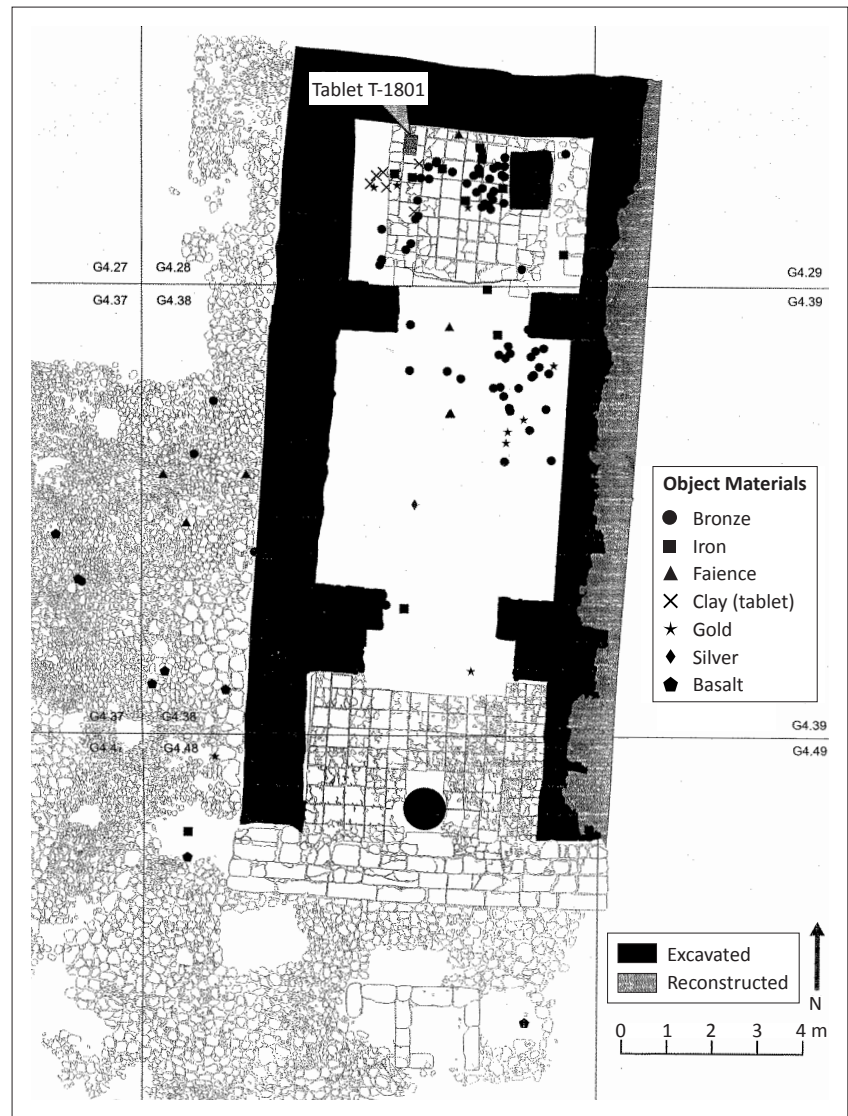

Source: Harrison, T.P. \& Osborne, J.F., 2012, 'Building XVI and the Neo-Assyrian sacred precinct at Tell Tayinat', Journal of Cuneiform Studies 64, 138. http://dx.doi.org/10.5615/jcunestud.64.0125, Figure 8

The arrow labelled T-1801 indicates where the Esarhaddon's Succession Treaty tablet has been found.

FIGURE 3: Map of temple XVI at Tell Tayinat.

When the people of Kullania renewed their loyalty oath, the tablet may have been taken out from the inner sanctum and brought to the portico with the column at the entrance in order to be shown and read to a greater audience.

\section{Bethel}

The mentioning of Bethel and Anat-Bethel in EST § 56C raises the question whether these deities allude to the sanctuary of Bethel in the southern part of the Assyrian province Samerina. Perhaps the tablet of this province was kept in a temple in the capital. However, the temple of Bethel was active during the Assyrian period (Koenen 2003:51f.). If 2 Kings 17:27f. is reliable, then the Assyrians fostered the veneration of the god of the land by sending a priest of Yhwh to Bethel. The god of the land persecuted the people through the sending of lions (2 Ki 17:25). Bethel is a place where Yhwh punished through lions (1 Ki 13). Bethel and Anat-Bethel punish by means of lions in the curses of Esarhaddon's treaties.

The Phoenicians regarded Bethel as the divine brother of El (Koenen 2003:81). The military colony at Elephantine venerated Yhwh, Bethel, Anat-Bethel and Anat-Yhwh. Anat is El's daughter at Ugarit in the 12th century BC - she may have been Yhwh's daughter at Elephantine in the 5th century BC (Day 1999; Becking 2003, 2011). The Assyrian curses of the 7th century $\mathrm{BC}$ invoke her in relation to (El of) Bethel.
Hence, it is arguable that El and Bethel were conflated in some regions and periods (Röllig 1999; cf. Niehr 2003:189). Bethel may be an abbreviation of 'El of Bethel' and may thus hypostatise El. In any case, Aramaeans and Assyrians called on a godhead that was believed to exercise power over the region of ancient Tyre and beyond. Israelites, living in southern vicinity of Tyre, and Judeans would have named this godhead Yhwh. It is not unusual in religious language that an in-group uses a different word than people who label a phenomenon from the outside. Hence, Assyrians might well have had difficulty in distinguishing Yhwh, the god of Bethel (a city in their province Samerina) from the god Bethel. If this reasoning is sound, the EST invoked Yhwh, calling him Bethel.

\section{Jerusalem}

The temple at Jerusalem comprised a holy of holies, the main room of the sanctuary, a vestibule or portico, and courts. In comparison to temple XVI at Tell Tayinat, the EST tablet may have been on display in the main room of the Jerusalem temple, which was furnished with different objects. It is improbable that access to the main room of the sanctuary was restricted to Levites at the time of Manasseh. Even sons of David functioned as priests, according to 2 Samuel 8:18. Most likely, the cuneiform tablet on display in the temple aroused the curiosity of Judean scribes and their ambition to create something similar. There were scribes in royal service who executed power in the temple (2 Ki 22:3; Jr 26:24). Priests and Levites were erudite and keen to know what sort of text the Assyrians and Manasseh forced them to display in their sanctuary. The Assyrian language, a Semitic tongue like Hebrew, was not any more difficult to learn for Jerusalem scribes than is English for speakers of other Germanic languages today. Some of the scribes were probably sent to study in Niniveh. In addition, the juridical or epistolary texts that they might have had to read in Assyrian cuneiform script, employed a restricted amount of word signs and syllables, whose memorising demanded considerably less effort than learning the 2000 most common Japanese Kanji today. The sophistication of scribal skill in composing texts using numerical repetition of keywords resembles the practice of composers of music in Baroque times. Similar to Johann Sebastian Bach adapting the melody of Giovanni Battista Pergolesi's Stabat Mater to become the theme tune of his Psalm 51, Judean scribes might have been tempted during Manasseh's reign to try their skills in composing an oath similar to that of Esarhaddon's chancellery.

\section{How the book of Deuteronomy may have been composed}

Deuteronomy exhibits extensive dependence upon biblical and non-biblical sources. The primary examples in each of these categories are the Covenant Code (Ex 20:23-23:19) and the Neo-Assyrian Succession Treaty of Esarhaddon. Yet, if Deuteronomy is largely derivative of literary precursors, it is also decidedly creative and actively revising those sources (Levinson \& Stackert 2012:125). 
Emergence of what would later on become Deuteronomy, possibly began with a pamphlet that communicates the centralisation of cult at the temple of Jerusalem in Hezekiah's reign before $701 \mathrm{BC}$. Whether the temple of Arad was given over to disuse in the 8 th or 7 th century $\mathrm{BC}$ became a matter of dispute. Recent reevaluation of the excavation records, however, speaks in favour of the idea that Hezekiah closed the rural temples before Senacherib's invasion in order to avoid the shame of Yhwh's sanctuaries being looted by the Assyrians (cf. Pietsch 2013:334-337, 475). This pamphlet is the kernel of Deuteronomy 12. In 672 BC, a tablet of the EST was sent to Jerusalem and went on display in the temple. Scribes, discontented with their order during Manasseh's reign to administer compulsory labour and military service for Assyria amongst their compatriots, cast their hopes on a benevolent divine overlord replacing the king of Assyria and executed their literary ambition in creating a loyalty oath for Yhwh. The discontent of some officials with the government led to a revolt against Manasse's heir, Amon (2 Ki 21:23f.). Eight-year-old Josiah was made king and he was apparently educated well by his scribal schoolmasters to become the best king since David (2 Ki 22:2; 23:25).

Levinson argues for Deuteronomy being a 7th century BC composition that revises both the Covenant Code and Esarhaddon's Succession Treaty. When creating the Judean loyalty oath, EST § 10 (11. 108-122) was subjected to creative revision in composition of Deuteronomy 13:2-12 (Levinson \& Stackert 2012:131). The same is true for EST § 56 being the model for Deuteronomy 28:20-44. The insertion of those commandments that draw upon the Covenant Code may have happened at a later period. The Hebrew oath was originally nothing more than a literary essay consisting of Hezekiah's pamphlet (Dt 12*), a kernel of Deuteronomy 13, some additional privileges of Yhwh resembling those of Exodus 34, and the kernel of Deuteronomy 28. Not being published after its composition during the reign of Manasseh, it was later forgotten. When Josiah initiated a restoration of the temple, this document was rediscovered and presented to the king.

Michael Pietsch dedicated his Habilitationsschrift to Josiah's cult reform. In contradiction to some scholars who judge 2 Kings 22f. as mere invention, his analysis led to the conclusion that the narrative about the finding of the book (2 Ki 22:3-10) corresponds to what would seem plausible to contemporary readers. Josiah's cultic reform is a historical fact (Pietsch 2013:472f.). In 622 BC, Josiah swore his loyalty oath before Yhwh, binding himself and his people to the text discovered in the temple and approved by the prophetess Huldah. After 622 and before Josiah's death in 609, scribes combined the Hebrew loyalty oath (Dt $13^{*}$ etc.; $28^{*}$ ) and a revision of the Covenant Code (Dt $14-15^{*} ; 19-25^{*}$ ) in order to create an Ur-Deuteronomium as a part of DtrL, the Deuteronmistic account of the conquest of Israel comprising parts of Joshua. Sooner or later, the book became a speech of Moses, and the alternative introductions in Deuteronomy 28:1, 15, the blessing in Deuteronomy 28:3-14, as well as the 'arur-formulas in Deuteronomy 28:16-19, were added according to the Levantine treaty tradition. During the exile,
Deuteronomy 28 grew in at least two stages (Steymans 1995:313-354, 377-383), with the whole Deuteronomy being edited in Deuteronomistic layers that get different labels, even amongst scholars of the so-called Göttingen school (Steymans 2011).

\section{Conclusion}

According to T-1808 from Tell Tayinat, it is safe to argue that copies of the EST were on display in Ekron, as well as in Jerusalem, both being vassal states of Esarhaddon's empire. The Jerusalem copy roused the curiosity of Judean scribes and their ambition to create a similar Hebrew oath. There is no curse sequence known from ANE documents that parallels EST § 56 with respect to topic, vocabulary and syntax as does Deuteronomy 28:20-44*. Future research may investigate the EST more carefully, asking whether or not there are more textual links with Deuteronomy than just those between EST $\S 10,12$ and 56 and Deuteronomy 13:2-12 and 28:20-44*. The connections between the Esarhaddon's Succession Treaty and Deuteronomy provide an 'Archimedean point' for dating the beginning of the literary history of Deuteronomy to the middle of the 7 th century BC.

\section{Acknowledgements}

The author is indebted to Melanie Delpech (Freiburg) for correcting the English of his article.

\section{Competing interests}

The author declares that he has no financial or personal relationship(s) that may have inappropriately influenced him in writing this article.

\section{References}

Becking, B., 2003, 'Die Gottheiten der Juden in Elephantine', in M. Oeming \& K. Schmid (eds.), Der eine Gott und die Götter: Polytheismus und Monotheismus im antiken Israel, pp. 203-226, Theologischer Verlag, Zürich. (Abhandlungen zur Theologie des Alten und Neuen Testaments 82)

Becking, B., 2011, 'Yehudite identity in Elephantine', in B. Becking (ed.), Ezra, Nehemiah, and the construction of early Jewish identity, pp. 128-142, Mohr Siebeck, Tübingen. (FAT 80).

Braulik, G., 2011, 'Die deuteronomistische Landeroberungserzählung aus der Joschijazeit in Deuteronomium und Josua', in H.-J. Stipp (ed.), Das deuteronomistische Geschichtswerk, pp. 89-150, Lang, Frankfurt. (Österreichische Biblische Studien 39).

Carroll, R.P., 1986, Jeremiah: A commentary, SCM Press, London. (OTL).

Day, P.L., 1999, 'Anat', in K. van der Toorn, P.W. van der Horst \& B. Becking (eds.), Dictionary of Deities and Demons in the Bible, 2nd edn., pp. 36-43, Brill, Leiden.

Dion, P.E., 1991, 'Deuteronomy 13: The suppression of alien religious propaganda in Israel during the late Monarchical era', in B. Halpern \& D.W. Hobson (eds.), Law and ideology in Monarchic Israel, pp. 147-216, JSOT Press, Sheffield. (JSOT Series 124).

Harrison, T.P., 2009, "Neo-Hittites in the "Land of Palistin". Renewed investigation at Tell Tacyinat on the Plain of Antioch', Near Eastern Archaeology 72(4), 174-189.

Harrison, T.P. \& Osborne, J.F., 2012, 'Building XVI and the Neo-Assyrian sacred precinct at Tell Tayinat', Journal of Cuneiform Studies 64, 125-143. http://dx.doi.org/ 10.5615/jcunestud.64.0125

Hasegawa, S., 2012, Aram and Israel during the Jehuite dynasty, Walter de Gruyter, Berlin. (BZAW 434).

Kinnier Wilson, J.V., 1962, 'The Kurba'il Statue of Salmanassar III', Iraq 24, 90-115.

Kitchen, K.A. \& Lawrence, P.J.N. (eds.), 2012, Treaty, law and covenant in the Ancient Near East, 3 vol., Harrassowitz, Wiesbaden.

Koch, C., 2008, Vertrag, Treueid und Bund: Studien zur Rezeption des altorientalischen Vertragsrechts im Deuteronomium und zur Ausbildung des Bundestheologie im Alten Testament, W. de Gruyter, Berlin. (BZAW 383)

Koenen, K., 2003, Bethel: Geschichte, kult und theologie, Universitätsverlag, Freiburg. (OBO 192). 
Koenen, K., 2006, 'Bethel [Gott]', viewed 07 August 2013, from www.alt.bibelwissen schaft.de/nc/wibilex/das-bibellexikon

Kratz, R.G., 2011, 'Die Worte des Amos von Tekoa', in R.G. Kratz (ed.), Prophetenstudien. Kleine Schriften II, pp. 310-343, Mohr Siebeck, Tübingen. (FAT 74). [= 2003, 'Die Worte des Amos von Tekoa', in M. Köckert \& M. Nissinen (eds.), Propheten in Mari, Assyrien und Israel, pp. 54-89, Vandenhoeck \& Ruprecht, Göttingen. (FRLANT 201).]

Lauinger, J., 2012, 'Esarhaddon's succession treaty at Tell Tayinat: Text and commentary', Journal of Cuneiform Studies 64, 87-123. http://dx.doi.org/10.5615/ jcunestud. 64.0087

Le Roux, J.H., 1994, 'In search of Carroll's Jeremiah (Or: Good old Jerry, did he really live? Question irrelevant!)', Old Testament Essays 7, 60-90.

Levinson, B.M. \& Stackert, J., 2012, 'Between the Covenant Code and Esarhaddon's Succession Treaty: Deuteronomy 13 and the composition of Deuteronomy', Journal of Ancient Judaism 3, 123-140.

Lohfink, N., 1997, 'Landeroberung und Heimkehr: Hermeneutisches zum heutigen Umgang mit dem Josuabuch', Jahrbuch für Biblische Theologie 12, 3-24.

Lohfink, N., 2000, 'Geschichtstypologisch orientierte Textstrukturen in den Büchern Deuteronomium und Josua', in N. Lohfink (ed.), Studien zum Deuteronomium und zur deuteronomistischen Literatur, vol. 4, pp. 75-103, Verl. Kath, Bibelwerk, Stuttgart (Stuttgarter biblische Aufsatzbände 31. Altes Testament).

Mallowan, M.E., 1958, 'Forword to the Vassal-Treaties of Esarhaddon by D.J. Wiseman' Iraq 20, i-ii.

Niehr, H. 2003, Ba'alšamem: Studien zu Herkunft, Geschichte und Rezeptionsgeschichte eines phönizischen Gottes, Peeters, Leuven. (Studia phoenicia 17, Orientalia Lovaniensia analecta 123).

Oates, D., 1957, 'Ezida: The Temple of Nabu', Iraq 19, 26-39.

Otto, E., 1999, Das Deuteronomium: Politische Theologie und Rechtsreform in Juda und Assyrien, Walter de Gruyter, Berlin. (BZAW 284).

Otto, E., 2002, Gottes Recht als Menschenrecht: Rechts- und literaturhistorische Studien zum Deuteronomium, Harrassowitz, Wiesbaden. (Beihefte zur Zeitschrift für altorientalische und biblische Rechtsgeschichte 2).

Parpola, S. \& Watanabe, K., 1988, Neo-Assyrian treaties and loyalty oaths, Helsink University Press, Helsinki. (SAA 2).

Pietsch, M., 2013, Die Kultreform Josias: Studien zur Religionsgeschichte Israels in der späten Königszeit, Mohr Siebeck, Tübingen. (FAT 86).

Pohlmann, K.-F., 1996, Das Buch des Propheten Hesekiel (Ezekiel), vol. 1, Vandenhoeck \& Ruprecht, Göttingen.

Pohlmann, K.-F., 2008, Ezechiel: Der Stand der theologischen Diskussion, Wissenschaftliche Buchgesellschaft, Darmstadt.
Radner, K., 2006, 'Assyrische uppi adê als Vorbild für Deuteronomium 28:20-44?', in M. Witte, K. Schmid, D. Prechel \& J.C. Gertz (eds.), Die deuteronomistischen Geschichtswerke: Redaktions- und religionsgeschichtliche Perspektiven zur 'Deuteronomismus'-Diskussion in Tora und Vorderen Propheten, pp. 251-278, W. de Gruyter, Berlin

Radner, K., 2006-2008, 'Provinz, C. Assyrien', in M.P. Streck (ed.), Reallexikon der Assyriologie, vol. 11, pp. 42-68. PMid:135312.

Richter, W., 1991, Biblia Hebraica transcripta (Numeri, Deuteronomium), vol. 3, EOS Verlag, St. Ottilien. (Arbeiten zu Text und Sprache im Alten Testament 33.3).

Röllig, W., 1999, 'Bethel', in K. van der Toorn, P.W. van der Horst \& B. Becking (eds.) Dictionary of Deities and Demons in the Bible, 2nd edn., pp.173-175, Brill, Leiden.

Rudnig-Zelt, S., 2006, Hoseastudien: Redaktionskritische Untersuchungen zur Genese des Hoseabuches, Vandenhoeck \& Ruprecht, Göttingen.

Steymans, H.U., 1995, Deuteronomium 28 und die adê zur Thronfolgeregelung Asarhaddons. Segen und Fluch im Alten Orient und in Israel, Universitätsverlag, Freiburg.

Steymans, H.U., 2000, 'Die Vereidigten Asarhaddons: Beobachtungen zur Textkritik, Dependenzgrammatik und Semantik des Sukzessionseids (SAA 2 6)', Thesis to obtain the degree of Master of Philosophy, Faculty of Humanities, University of Vienna.

Steymans, H.U., 2003, 'Die neuassyrische Vertragsrhetorik der "Vassal Treaties of Esarhaddon" und das Deuteronomium', in G. Braulik (ed.), Das Deuteronomium, pp. 89-152, Peter Lang, Frankfurt.

Steymans, H.U., 2004, 'Asarhaddon und die Fürsten im Osten: Der gesellschaftspolitische Hintergrund seiner Thronfolgeregelung', in F. Schipper (ed.), Zwischen Euphrat und Tigris: Österreichische Forschungen zum Alten Orient, pp. 61-85, Lit-Verlag, Wien.

Steymans, H.U., 2006, 'Die literarische und historische Bedeutung der Thronfolgevereidigung Asarhaddons', in M. Witte, K. Schmid, D. Prechel \& J.C. Gertz (eds.), Die deuteronomistischen Geschichtswerke: Redaktions- und religionsgeschichtliche Perspektiven zur 'Deuteronomismus'-Diskussion in Tor und Vorderen Propheten, pp. 331-349, W. de Gruyter, Berlin. http://dx.doi.org/ 10.1515/9783110927344.331

Steymans, H.U., 2011, 'DtrB und die adê zur Thronfolgeregelung Asarhaddons? Bundestheologie und Bundesformular im Blick auf Dtn 11', in G. Fischer, D. Markl \& S. Paganini (ed.), Deuteronomium - Tora für eine neue Generation, pp. 161-192, Harrassowitz, Wiesbaden.

Strawn, B.A., 2005, What is stronger than a lion? Leonine image and metaphor in the Hebrew Bible and the ancient Near East, Academic Press/Vandenhoeck \& Ruprecht, Fribourg/Göttingen. (OBO 212).

Wiggermann, F.A.M., 1992, Mesopotamian protective spirits: The ritual texts, Styx \& PP Publishers, Groningen.

Wiseman, D.J., 1958, 'The Vassal-Treaties of Esarhaddon', Iraq 20, 1-99. 